\title{
Religious Processions: Urban Politics and Poetics
}

\author{
LILY KONG \\ National University of Singapore
}

\begin{abstract}
In this paper, I will explore the ways in which processions, by their very visibility, foreground the relationships between the secular and the sacred, while contributing to a construction of identity and community, and simultaneously surfacing fractures therein. Using the example of multireligious yet secular Singapore, I will examine (a) the state's management of religious processions, including the regulation of time and space for such events, as well as regulations over noise production; (b) the tactics of adaptation, negotiation and resistance that participants engage in at an everyday level in response to the state's ideologies, policies, laws and strategies; (c) the participants' experience of these processions in terms of the sense of communitas that Turner describes but which Eade and Sallnow dispute, through emphasis on faultlines within "community" based on age, class and nationality; (d) the investment of sacred meanings in these processions by participants and the nature of their "sacred experience"; and (e) the manner in which such activities, associated state actions and participants' responses evoke reactions from non-participants within and beyond the specific religious group, exploring variations, from obvious fractures between groups to curiosity to enthusiastic support. My specific case focuses on Thaipusam processions in Singapore as one of the most colourful, organized and long-lasting religious processions.
\end{abstract}

Processions have traditionally been an integral part of religious life. They are often among the most visible of religious activities in public spaces, and to that extent, have the greatest opportunity for contact with secular activities and religious practices of other faiths. Because they tend towards the "spectacular", the potential for conflict is heightened. As events which attract 
crowds, the possibility of violence and aggression is real, as experience in many countries reminds us. The politics of such events must be understood, in order to avoid the troubles apparent in different parts of the world. At the same time, to understand the politics of processions, it is imperative to understand the meanings and values invested in such events - in short, the poetics - not least because it enables policy-makers and enforcement agencies to become aware of what sacred meanings are negotiable and what should remain fixed values.

Much of the geographical literature on processions addresses secular processions, including national parades (Kong \& Yeoh 1997), and community parades such as Carnival in London (Jackson 1988; Lewis \& Pile 1996), the Rose Parade and the Doo Dah Parade in Pasadena, California (Lawrence 1982). The closest literature focusing on religion deals with pilgrimages (see Kong 1990; 2001). Indeed, there are many similarities between the nature and experience of processions and pilgrimages, though the latter is on a larger scale, often traversing greater distances, involving greater commitment of time, and possibly enduring more privations. In drawing on insights from existing literature therefore, I engage with the literature on both secular processions and religious pilgrimages.

How has modern society and its many secular influences impacted the practice of processions? Campo $(1998,42)$ forcefully argued that

[...] the modern nation-state, the world capitalist system, steel, plastic, the telephone, the locomotive, the automobile, the airplane, the television, and - yes - the computer are making it possible for greater numbers of people in more cultures to learn about, travel to, and see more sacred places faster than at any other time in human history. A significant result of this has been that the number and variety of sacred places have also increased dramatically.

Following this observation, it would appear that processions and pilgrimages continue to be a significant aspect of religious experience in the contemporary world. What, though, is the nature of this experience? In particular, in modern cities where functionalist urban planning may come 
up against sacred pilgrim sites, and where Hindu, Jew, Buddhist, Christian and Muslim may live cheek by jowl, what sorts of conflicts have to be negotiated in the continued performance of such religious practice? I explore this question using the multicultural, multireligious case of Singapore, a modern city and officially secular state where all the major world religions are represented, with many more new religions emerging. This analysis may be characterized as a focus on the micro-politics of urban life and its conflicts, and is pursued on the basis that such micro-politics is constitutive of the macro-politics of religious conflicts manifested in religiously-based wars and unrest, such as in Palestine, Northern Ireland, South Asia and so forth. Such macro-politics, I would argue, have historical roots, but are also daily constituted and reinforced through a micro-politics of friction that often appear less dramatic, less serious, less pressing than the drama and spectacle of macro-politics, but which nevertheless are very real and influential for their role in the warp and woof of everyday life.

\section{Processions and Pilgrimages: Some Approaches}

As indicated earlier, there is a literature on the phenomena of religious pilgrimages and one on secular processions. These two sets of writings offer inspiration and insights to my analysis.

Pilgrimage is a "social construction, and inevitably, a cultural product" (Graham \& Murray 1997, 389), in the same way that the sacred is imagined and articulated within cultural practice. The cultural product must, in turn, be understood in relation to its social, political and historical contexts. The multidisciplinary literatures on pilgrimage recognize this social and cultural constructedness, and in so doing, also acknowledge how social relations are (re)enacted or challenged during pilgrimages, resulting on occasion in conflict but also in reinforcement of community and identity.

Due to the influence of anthropologist Victor Turner (1974), pilgrimages are thought to temporarily bring together individuals disparate in age, occupation, gender, ethnicity, social class, power and wealth. Pilgrimages bond together, "however transiently, at a certain level of social life, large 
numbers of men and women who would otherwise never have come into contact" (Turner 1974, 178). Pilgrimages therefore function "as occasions on which communitas is experienced and as journeys toward a sacred source of communitas which is also seen as a source of healing and renewal" (Eade \& Sallnow 1991, 203). Pilgrimage, in this sense, is a liminal experience, involving abrogation of secular social structure. For example, Young (1993) argues that on the hajj, social relations depart from that in daily life in that women are not secluded, are not subject to the authority of men (other than that of the neutered aghawat i.e. chieftains), and are not less involved in commerce than men. The inversion of everyday social relations is also evidenced in symbolic terms, as when the hierarchy of the church is turned upside down in the case of Medjugorje. The Catholic Church is such that the authorities lead and teach laypersons, and the authorities are invariably adult, male clergy. At Medjugorje, the visionaries are young, predominantly female, and laypersons - those who "traditionally have little voice in the church" (Jurkovich \& Gesler 1997, 460).

On the other hand, scholars such as John Eade and Michael Sallnow (1991) argue that pilgrimage is a pluralist experience, a realm in which there are competing religious and secular discourses, leading to the reinforcement of social boundaries and distinctions rather than their dissolution. Graham and Murray (1997) are well persuaded by this argument, and illustrate how it is the case through a study of the Christian pilgrimage to Santiago in northwest Spain. The Camino, as it is popularly known, is variously appropriated by different groups, investing diverse meanings that are sometimes conflicting with one another. First, the Catholic Church continues to attempt to stamp its papal authority and the importance of the spiritual over secular values. Second, the Council of Europe calls upon Santiago to remind people of the ideal of European integration, designating it the European Capital of Culture in the year 2000. The motif symbolising the Camino - the pilgrimage route - is designed to represent the roads of Europe symbolically joining and leading to Santiago, no longer a ceremonial centre of Spanish nationalism. Third, governments of the regions through which the pilgrimage route 
passes have sought to market it, engaging in a process of image production and material practices. This represents the "economic commodification of heritage" (Graham \& Murray 1997, 399). Beyond these official discourses, there is also a "vigorously disputed set of non-official social distinctions" (Graham \& Murray 1997, 404) regarding what constitutes a "true pilgrim", from those who see it as personal privation from a puritan perspective to the liberal/humanist view that "correct" attitudes towards pilgrimage are sufficient without need to heighten suffering (Graham \& Murray 1997, 402-405).

The multiple meanings of the pilgrimage route give rise to tensions and conflicts, as the authors argue in another paper (Murray \& Graham 1997). In particular, the modification of religious meanings as a result of tourism reveals the conflicting motivations and demands of pilgrims and tourists. Thus, Santiago de Compostela's dominant religious meaning as a pilgrimage destination became modified into a city of culture; the Cathedral of Santiago from a place of prayer and worship to a heritage attraction; the Feast Day of St James from ritual to special-event tourism; relic-touching from devotion to good luck/the wishing well; the Compostela from expiation to certification of achievement; pilgrim ways from penance/punishment to self-renewal and off-road adventure trails and so forth. Pilgrimage routes and sites even become embellished, as when a new site is introduced along the route to attract tourists, such as the dinosaur footprints mythically linked to the hoof marks of St James' horse!

Such commercialization is also apparent in the famous Catholic site, Medjugorje. Shopkeepers set up their wares near the church grounds to capitalise on the presence of pilgrims, producing unofficial religious articles, which has created tensions with local church officials. Warring ethnic groups have emblems which have also been commercialised (e.g., badges and pins with their symbols), and sold alongside rosaries and Madonna statues. New cafes, bars and pizzerias have been introduced, resulting in the "look and feel of a beach resort", creating placelessness and inauthenticity (Jurkovich \& Gesler 1997, 462-463). 
These studies illustrate the multiple meanings and pluralist experiences associated with pilgrimage routes and sites, at times coexistent in peaceful if uneasy parallel, at other times conflicting in both discursive and material realms. Religious processions, on a scale smaller than pilgrimages, nevertheless encapsulate many of the issues confronted in pilgrimage analysis, and indeed, are not unlike the experience of secular processions, of which analyses exist of pageants, parades and Carnival.

Drawing from a range of studies, it may be said that parades and processions "[serve] as a means to focus attention of private people on their collective life and the values they [espouse] through it" (Goheen 1993, 128). Their performance in public streets turn them into "a particular space, a landscape that could be exploited effectively through the collective performance of particular rituals to communicate, legitimate, and politicize values" (Goheen 1993, 128). Not only do they mark out space, but such "civic rituals" also represent "time apart", for they are "time separated from the normal activities" (Goheen 1993, 128). These rituals also stress shared values and reinforce group cohesion by emphasising belonging. Further, "parades and other forms of mass public ritual [may be] characterized as demonstrations of community power and solidarity and serve as complex commentaries on the political economy or urban-industrial social relations" (Marston 1989, 255). As Kaplan $(1984,189)$ explained:

Civic rituals, closely associated with a sense of community in cities such as Barcelona, often cut across class lines. Whether organized for religious, folkloric, or political reasons, urban pageants carried with them a measure of solidarity that surpassed the elements of ritual content.

On the other hand, these events may also reflect the spatial constitution of symbolic resistance, achieved through the symbolic reversal of social status (Jackson 1988). They offer a temporary respite from normal relations of subordination and domination, and thus, offer a potential platform for protest, opposition and resistance (Jackson 1988, 222). In the case of Notting Hill Carnivals in London, authorities strive to keep the Carnival to the road 
because of its potential as a threat to the social order (Jackson 1988, 223), reflecting the spatial strategy associated with power and control.

Yet, as Jackson $(1988,216)$ points out, the symbolic reversal of social status during Carnival should not be confused with subversion because it only serves to reaffirm the permanence of the social hierarchy. What Carnival offers is a temporary respite from normal relations. In this way, Carnival is a "social leveller", allowing for "a harmless release of tension, and a force for social integration" (Jackson 1988, 215).

\section{Fieldwork Context}

Thaipusam is celebrated by ethnic communities hailing from South India in many parts of the world, such as Fiji, Mauritius, Trinidad, Durban in South Africa, Toronto in Canada, Malaysia and Singapore. In places like Chennai (formerly Madras) in India and Jaffna in Sri Lanka, the event is an important celebration for Tamil communities. The festival marks the birthday of Lord Subramaniam, one of the sons of Shiva. The spectacle of the event revolves around a device called a kavadi carried by many of the participants along a processional route. Some participants may even pierce themselves with skewers or attach hooks to their bodies. The processions are generally accompanied by music and chanting. Some participants also enter a religious trance during the procession. Generally, those who take part in the procession do so as a form of thanksgiving for prayers answered.

In Singapore, Thaipusam is a colourful annual event which has evolved over the years, as has the state's management of this public event. Religious processions in Singapore are carefully monitored and managed, a caution rooted in an unfortunate historical episode. On 21 July 1964, during a procession celebrating the birthday of Prophet Muhammad, riots broke out as the Malay-Muslim procession passed through Kallang, a predominantly Chinese populated area. Different accounts exist of how the riots started. One account suggests that someone threw a bottle at the participants. Another suggests that someone jeered at the participants, leading to a fight. Yet another has it that the riots were politically motivated (National Archives 
website). Whatever the cause, given this historical precedent, a range of measures has been put in place to manage public processions, including Thaipusam.

Two Hindu community leaders closely associated with the Thaipusam festival shared many insights into the organisation of the kavadi procession. Annually, two to three months before Thaipusam, an application has to be made by the Hindu Endowments Board (HEB) on behalf of the two temples involved (marking the starting and ending point of the procession respectively) and participating devotees, to the police to obtain a permit to hold the procession. Additionally, along the processional route, tents are usually set up by Hindu devotees, serving either water or milk to those participating in the procession. Tent owners also have to apply to the police for permits after seeking endorsement from the HEB. Following these applications, the police will convene a meeting with the HEB and representatives from the two temples to discuss the ground rules and the problems encountered during the last festival, with a view to proposing ways of addressing the problems.

Almost 10,000 participants can be expected annually, with more than 8,000 carrying milk pots, and more than 1,000 carrying kavadis. Additionally, there are many more who set up tentage, and others who help the devotees. With this scale of events, the temples have a huge logistical task. The two temples thus issue "rules, regulations and conditions governing Thaipusam", constructed to observe state rules pertaining to assemblies and processions (encapsulated in the Miscellaneous Offences [Public Order and Nuisance] Act and its related subsidiary legislation), and to help the temples manage the event. Individual kavadi carriers have to buy tickets from the temples to participate in the procession and pay a fee to defray the cost of organizing the event and handling the logistics. Big kavadi carriers pay more because they "take up the most space and need the most supervision" (Straits Times, 23 Dec 1999). Kavadi carriers have to inform the temples of the size and weight of their kavadis, which should not exceed certain limits (4 $\mathrm{m}$ from the ground up and $2.9 \mathrm{~m}$ in diameter), so as to ensure that they will 
not pose safety hazards, either to traffic or street wires. Devotees carrying milk pots may leave Perumal Temple from 2.00 a.m. onwards on Thaipusam Day but kavadis and rathams (shrines on wheels) have between 7 a.m. and 7.30 p.m. to leave the Perumal temple. At the other end, the doors of the Thendayuthapani Temple will be closed at 10 p.m. When tickets are issued at point of payment, devotees are given specific times when they should assemble at the starting point, in order that the crowds may be managed. Further, no forms of musical instruments (traditional or otherwise) and recorded music/songs are allowed along the processional route, and only holy music is allowed within the temples' premises. The temples' rules end with a warning that any infringement of the rules by devotees and/or supporters will be subject to prosecution by the police and the devotees being barred from participating in future Thaipusam festivals.

The perspective of the Hindu Endowments Board, expressed by one of its officers is as follows:

We try to follow the rules and regulations as closely as possible because we do not want to lose this privilege like what happened to the Mohammed procession (personal interview, 27 June 2001).

Historical precedent - the 1964 Muslim procession which erupted into riot and led to its subsequent discontinuation - becomes the basis on which the Hindu leadership submits to contemporary state regulatory forces.

Over a number of years, from 1999, I have been an observer of Thaipusam festivals, and have interviewed participants and observers about a range of issues, from their experience of the procession to their reactions to some of the strictures introduced over time. Participants ranged from those who carried kavadis and milk pots to those who helped organize the event to those who assisted their friends and family members. Observers included both Hindus and non-Hindus along the processional route. Pseudonyms are used below where verbatim quotes are shared. 


\section{Religious Processions and the Making of Social Relations}

Susan Davis' $(1986,6)$ description of $19^{\text {th }}$ century Philadelphia parades as "public dramas of social relations" provides an apt perspective for examining the Thaipusam procession in Singapore. Just as the $19^{\text {th }}$ century parades "define who can be a social actor", Thaipusam was both an occasion for boundary-making and one for reinforcing social ties, in particular, religious community, family and friendship ties.

As an occasion for boundary-making, observations of Thaipusam remind us that a community is not devoid of internal tensions, and is not always characterized by homogeneous, or even consensual, traits, experiences and views. Thus, boundaries are both internal to the Hindu community as they are between the Hindu and other communities in multi-religious Singapore. The procession surfaced conflicts and tensions within the community, evident in two main ways. First, the latent discontent with a prominent foreign worker population in Singapore, and in this particular instance, when a foreign Indian worker population, was foregrounded in a public performance such as Thaipusam, with crowdedness and disorderliness attributed to them. One interviewee complained that the procession had become very protracted, with many delays, because of the growth in the number of kavadi carriers, and the larger crowds. He attributed this to the increase in the number of foreign workers participating. Another intimated that "Thaipusam has been spoilt" because of the intrusion and rowdiness of "foreign elements". Not all interviewees, however, blamed the foreign workers, with many pointing fingers at "the younger generation" instead. Like several other interviewees, Kalpana, a clerk in her late 30s, blamed the "youngsters", "the way they dance, the way they cheer, the way they change those movie songs to God songs". Boundary-making thus drew on age, class and nationality as divisive factors.

The consciousness of "self" and "other" was also evident through repeated references to boundaries between the Hindu community and other communities. These references revealed an awareness that this very public display of Hinduism had the power to shape public perceptions about the 
Hindu community, and also offered the occasion for the "other" to show an understanding of, and sensitivity to, the Hindu community. In the former instance, Hindu interviewees referred again to the unruly behaviour of some young Hindu boys in the processions, and expressed deep regret that "you have other races watching you, so when all these happen, it gets wrong ideas into people's heads about us" (Selva, aged 40).

In the latter instance, some interviewees expressed disappointment at the lack of understanding and respect by other communities of the sacredness of the event:

Frankly speaking, it is okay for them to watch but I think there are members of the public who are not dressed properly and who don't behave well. I think this is kind of a distraction. We feel very offended when we are participating, you know. It is something that you don't like to see during the processions. We like somebody to be more pleasant, more properly attired rather than like coming all the way as though you are going for a show, going for a disco. I think in my case, I don't like it. (Shamala, late 30s.)

Inasmuch as the procession foregrounded occasions of internal and external boundary making, it was also an opportunity for the reinforcement of family and friendship ties, and the reaffirmation of community identity. At the most fundamental, the commitment to Thaipusam was viewed as a total family obligation, from pre-festival joint fasting and cleansing, to the provision of help and support during the procession itself. The most pronounced assertion of the role of the family was expressed by Mano, who has participated annually in Thaipusam for 27 years. He says:

I have seen cases where people take it just for granted. Ah, everybody carrying, I also can carry and everything. After they start walking, they just collapse. Just cannot fulfill the route. And some of them, you can see, when you're piercing, you can see them pinching because it's painful. It's hurting them and everything so. I wouldn't really say whether they did fast properly or not, but I know there's something wrong. Something is not right. Something is wrong in the family. Maybe they did not fast. Maybe in the 
house, in the family, something is wrong. When I want to carry the kavadi, the whole family joins in. We all fast together.

Like him, Mohan, also a frequent participant in Thaipusam, talks about how his son fasts with him prior to the event:

My son also tries not to bring back chicken rice or something and eat there. He knows we have the house clean for this festival. He said, "I will join my father, be a vegetarian".

This family involvement has the effect of bringing the family together, as Rama, a 41-year-old participant points out:

Usually, there is family involvement. Normally when we are involved, the family also has to follow the fast so that the house is kept clean and the prayers are done. It is a discipline, so it is not like, this only has to do with my family member, so I just don't bother. So it is, like I say, it brings the family together and I think also brings them spiritually together because everybody is helping each other.

Such family participation extends to the day of the procession itself, during which family and friends provide both practical and moral support. Practically, Mohan shares insights into the physical difficulties that one might encounter during the procession, and the need for help:

Just say for example, this big chariot which I carried, which I'm carrying. For some reason, if I can't pull it, somebody can help me to push. And if this big kavadi I'm carrying, for some reason I cannot carry, balance myself, the people all round, four of them, could hold me and you know... [help to] adjust it or just carry. And in the worst case, if you really cannot walk, they can dismantle it and bring you to the temple in whatever way they could help. Yes you need them to help because you will never know. While you're walking, the kavadi is about three metres high. All of a sudden, a strong wind may come. The whole thing can just... you may just fall out. When I'm pulling a chariot, you may find a small stone on the road and it will get stuck on the wheel. I can't come and lift it up you know, so I need friends and family to be 
around me to help me... That's why it's not just you yourself. I may be in the procession, but everybody is helping, also participating in this holy festival. And they are getting themselves involved in it one way or another.

Spiritually and emotionally, Rama acknowledges the need for support, when the journey gets long and delayed:

The procession is about four kilometers and at some point of time, there would be a jam, and we have to wait for two and half, three hours. During that period, family is there or friends or relations to give you the moral boost. So it is a group of friends.

But the strengthening of social relations is not confined to pre-existing family and friendship ties. The sense of community among participants and well-wishers is enhanced through the cheerful support given to participants completing the thanksgiving journey. As 23-year-old Vani explained:

Usually what happens is that after you are done with your procession, let's say you have already reached the temple, then it is when... that means you have finished your task already, right. So then, it doesn't have to be someone that you know. You can also carry on and cheer, cheer along with everybody else, even if it is strangers. It does not have to be someone you know. We cheer other participants along, to encourage them to the finish.

When probed, Vani and others were clearly conscious of myriad sub-groups, such as the boisterous youths and burgeoning foreign workers, and indeed expressed their annoyance and disapproval. Yet, their enthusiasm and support for participants, particularly when nearing the destination, were coexistent with their awareness of social difference. They would not admit to a sense of egalitarian association, of sameness that spells the abrogation of social structure, after the manner of Turner's (1974) communitas. Rather, it was a sense of support for those who have made sacrifices and bore the privations of the journey, not unlike support for sportspersons on the track or field. This did not amount to a numbing heap of emotions that culminates 
in "carnivalistic mésalliances" where the lofty is combined with the low, the great with the insignificant, the wise with the stupid (Folch-Serra 1990, 265), offering "temporary liberation from the prevailing truth ..." (Bakhtin $1968,10)$. The experience of communitas, long accepted in many anthropological writings about pilgrimage, did not replicate itself in the context of the Thaipusam procession in Singapore. This may suggest that pilgrimages and processions, because of the differences articulated above, are not directly comparable, but it may also suggest that the sense of sameness and egalitarian association may be a somewhat romanticized interpretation of the pilgrim experience.

\section{Religious Processions and the Negotiation of Poetics and Politics}

The making of social relations aside, religious processions also exist at the nexus of "poetic" performance and public politics, the negotiation of which forms the analysis in this section. Conceptually, I have framed the material in terms of the negotiation of soundscapes, timescapes and landscapes, reflecting the multiple dimensions of the processional phenomena.

\section{Negotiating Aural Space}

That Thaipusam occupies aural space and derives significant meaning from the manufacture and consumption of sound might not have been so apparent if that aspect of the event did not become subject to policy and policing. No interviewee failed to discuss the significance of music and/or chanting to the creation of the appropriate atmosphere and as an integral part of the ceremony. Many took pains to explain the place of music in religion and in this particular public performance. All spoke of the value of music in relation to its enforced absence in the context of Singapore's Thaipusam. Pany, an organizer of the event, shared this perspective:

Music is part of religion. If you notice, the drums, the long pipes played during prayers... traditionally, music, dances, language were performed in the temples, where culture was propagated. For the kavadi carriers, the music is 
to let them forget the pain and let them concentrate and to fulfill their mission, which is to carry the kavadi and milk offered to the deities.

However, over the years, restrictions have come to be placed on the noise level generated at public events, and as highlighted earlier, music and songs are not allowed along the processional route. This reflects a larger policy in Singapore, translated and experienced in a variety of contexts. For example, the traditional call to prayer in rural settings and small Muslim communities used to be done on a loudspeaker, outward from a mosque to signal to adherents prayer time. It became regulated because, in Singapore, population growth and urbanisation had meant that the new urban social setup had caused such sound production to sometimes be regarded as intrusive by those not involved in that religion or those particular events (Lee 1999). State regulations on "noise pollution" were therefore introduced, including turning the loudspeakers inwards towards the mosque rather than outwards, specifying acceptable noise levels for events such as Chinese operas, funeral processions, church bells, music during weddings, record shops and places of entertainment. Even state-endorsed and state-encouraged nation-building activities, such as the recitation of pledges in schools, were subject to these rules. Thus, the injunction on "noise" production during the procession may be understood within this context.

As a consequence, the desired "poetic" value of music as expressed by participants is curtailed, and has become embedded in a quest for aural space in religious activity. This politics of sound and space is in turn expressed in a variety of ways, from the most supportive to actions which attempt to circumvent the intent of the law. Elaborations below will demonstrate the range of reactions. At the one end of the spectrum, Vani expresses full support for the regulations:

I fully support the government doing this... because teenagers especially tend to take advantage if there are no rules, so they made the whole procession look like a hooligan get-together because they would dress in black and they end up taking garbage cans and turning them upside down like playing 
drums. So what happens was that it led to unnecessary fights because you have a lot of gangs here and a lot of gangs there and compete who can make more louder noise and stuff like that. So these were all unnecessary and you can find policemen arresting people. This is not supposed to be done when you are doing something sacred going on there. So after the restrictions were imposed, you can't find things like that now and it looks more festive.

Others accept but without the same sense of support, such as Rama, who points to Singapore's perceived political culture of compliance:

I think we just learn... you know we Singaporeans are so obedient. Okay I mean, as long as we feel that government says we obey, you know. So I think that's no problem. We may complain, we may complain but ultimately we still follow the rules.

Yet others hope for change, emphasizing the religious value of music and song, believing that "singing those holy songs" help the kavadi carrier to concentrate his attention on God, because "the moment the music stops, his mind will wander" (Selva). Two kavadi carriers share their experience thus:

You see when I walk in the procession without any music, I feel frustrated. Very. But when you hear the music, there is somebody singing about the Lord with the beautiful words and everything, and you automatically forget everything around you and you just gracefully dance with the music and I think that's the best thing to do. (Mohan)

On that day, from my personal experience, you hear the group singing with the music and they are singing religious hymns. You feel in touch with it physically and spiritually and also you don't think of the weight, you don't think of the pain or whatever. You are very focused because the atmosphere, the environment, the music, the air, the sound, they will give you spiritual upliftment. And then some people get into a trance because probably they get carried away by the music and are so deep in concentration that they get carried away and they start dancing. (Rama) 
While Selva believes the effect is "more psychological", Shamala believes it is spiritual, for "we believe that when we chant and call the lord, the lord will take away his pain". Kalpana, in turn, highlights the performative element of the procession as "an offering to the god".

In contrast, others are quite vituperative in their response. Mano, a vocal participant with clearly strong views, offers a strong critique and reveals the appeals that have transpired:

We asked the temple and everything. They said no, they said it's against the law. Most of them, some of them, even myself, sometimes I say walking like that, it's just like attending a funeral with no music and all. Makes us feel like that. Sometimes I should say with so many regulations and everything, so after a while you're fulfilling the vows and everything, you should do it happily. Wholeheartedly. Not with the thinking, cursing somebody. There's not music or anything so I hope the government will consider all these people's request. We have written in to the temple and asked them. As you can see, people are behaving better nowadays, some of the people, maybe slowly they will give you music or they can even put a music round maybe 100 metres because it's quite a religious day and it's recognized in the world as well. Everybody knows that Thaipusam is a very grand thing so maybe we should think of something, compromise somewhere and then make everybody happy. I hope something will work out.

For some, the appeal is built on the logic that if there are those misbehaving, action should be taken against them rather than to have a blanket ban on music, thus calling on the authorities to be more discriminatory in their strategies of management.

Finally, in a fairly circular way, some interviewees point out that it is because musical instruments are banned that there are those who circumvent that by using empty tin cans and dustbins for improvisation, thus resisting sanctions in symbolic ways:

These guys use dustbins. So when they see the police officer, they just put it down. After that they just pick it up again. (Shamala) 
[...] previously you were allowed to carry drums and all that so when they banned the drums and all that some of them started taking empty tins and knocking because it still makes the music you see. It's because if you confiscate the drum, they lose the drum. But if you want to confiscate the tin, they say, take the tin, feel free. Because it's just an empty tin, because they wanted the music, and there was no music. (Mohan)

Thus, the ban on music led to the creation of improvised sound, which in turn led to the perception amongst other participants and observers of a lack of respect and religious value, thus ironically prompting their support of a ban.

\section{Negotiating Sacred Time}

In as much as the poetics and politics of soundscapes are negotiated in the construction of an aurally defined sacred space, so too has the bracketing of time come to shape the practice of religion. In the history of religion, days and times of the day have traditionally been set aside for religious practice, what Eliade (1959) has refered to as "sacred time". Sacred time is thus that time during which religion is foregrounded, and is to be set apart from secular time. In contemporary society, what time is marked out as sacred is again a negotiated outcome between secular and religious agents. This is evident at two levels in the context of Thaipusam in Singapore: in the official appointment of public holidays tied to religious festivals, and in the allocation of time for religious activity in the public sphere. Indeed, apart from the choice of the day, other aspects of managing that time are much more guided by pragmatic secular considerations than religious ones.

In the official Singapore calendar, a series of public holidays are identified, corresponding to religious and cultural festivals: Vesak Day (Buddhist), Hari Raya Puasa Aidilfitri and Hari Raya Haji (Muslim), Deepavali (Hindu), Good Friday and Christmas (Christian), and New Year's Day and Chinese New Year. There are, additionally, the secular public holidays, Labour Day and National Day. While clearly acknowledging the multi-religious profile of the Singapore population, the choice of religious festivals that deserve 
public holiday status in many ways defines the extent of religious activity and participation that is facilitated for particular religious groups. Thus, several interviewees commented on how the lack of a public holiday for Thaipusam created difficulties for them. Shamala, for example, explained the inconveniences as she was not able to take time off work, and therefore had to participate in the procession very early in the morning or late in the evening. This in turn posed other problems - the extra cost of transportation in the early hours of the morning, recalling that milk pot bearers could start at 2 a.m. ("you have to pay double charges unless you have people to help you"), and the congestion in the post-work rush hour ("tempers flare for those in the traffic jam held up by us"). This is echoed by Pany who recounts as follows:

It is not a public holiday so everybody does it early morning... they get ready and start the first journey at 2 a.m. and hopefully they can get back by 5 and they can report to work, you see. Or they do it in the evening and when they do it in the evening, it ends very late. It can end as late as 12 or 1 a.m., causing a congestion and traffic jam at the entrance of the other temple so these are the inconveniences. I think because there is no public holiday, and the working people would try to finish it in the morning. I believe that if it is a holiday, then there is a free flow in the morning around 9 to 11, there will be people participating. But because of these restrictions, there is heavy traffic. There is heavy traffic early in the morning and heavy traffic late in the evening.

While the sacred day is not marked out in the secular calendar as a public holiday, the bracketing of time within the day itself is guided by temple regulations based on pragmatic considerations of crowd control and safety, as well as by self "regulation", again based on the pragmatics of tropical, urban living. Temple regulations stipulate that those carrying milk pots may start at 2 a.m. though kavadis and rathams may only begin at 7 a.m, with the last participant beginning at 7.30 p.m.. This bracketing of time is based essentially on pragmatic considerations, to spread out the activities over as many hours as possible to avoid congestion, and to have those with the bigger 
paraphernalia of kavadis and rathams out on the streets only after the break of light. Additionally, participants further bracket the time in view of the hot afternoon sun in tropical Singapore, so that few take to the streets during the afternoon hours. Whereas scholars of religion have written abundantly about sacred time as set apart from ordinary time, during which religious activities are propitious, in the context of Thaipusam processions, apart from the identification of a sacred day, which hours of the day particularly attract religious activity and which represent "down time" is guided more by pragmatic considerations than by religious ones.

\section{Negotiating Sacred Pathways}

The processional route, as I indicated earlier, begins from Sri Srinivasa Perumal in Serangoon Road and ends in Sri Thendayuthapani in Tank Road, a journey of some $4 \mathrm{~km}$. The former is in the heart of Singapore's Little India district, and the journey brings participants past a number of temples in that district. Previously, the route was symbolically significant because participants would wind past the Kaliaman ${ }^{1}$ Temple (known as the "mother's temple"), and the Sivan Temple (known as the "father's temple") in Dhoby Ghaut. Devotees passing these temples would therefore pay homage to the "mother" and "father". However, the Sivan temple was relocated from the Dhoby Ghaut area to a temporary site next to Sri Srinivasa Perumal in 1984 and then to a permanent site in Geylang East in 1993. This move occurred because of the construction of a mass rapid transit station where it stood, and despite appeals to the contrary, was relocated.

Since 1993, the deity Siva has been brought annually to the Perumal Temple on the eve of Thaipusam, staying there until the night of Thaipusam. This allows devotees to pay homage to the "father" from the start of the procession, before passing by the "mother" enroute to Sri Thendayuthapani. In short, despite the community's investment of symbolic meaning in the Sivan temple and its location, secular priorities prevailed, and ritual adjustments were introduced to manage secular changes that impact on religious practice.

\footnotetext{
${ }^{1}$ Kaliaman is the consort of Siva.
} 
This might be contrasted to observations of the value of symbolic meaning over pragmatic considerations in some other contexts. For example, Berger (1968, quoted in Davis 1985, 266), highlighted that the routes that public processions take are symbolically important because they "[significance] a 'capturing' or taking over of various parts of the city", the outcome of the sheer numbers of marchers "transform[ing] the areas through which they march into a 'temporary stage' on which they dramatize the power they still lack". In this account of Thaipusam, however, the state's control of the processional route and the resultant modifications to religious practice suggest that significant priority is given to secular needs over the symbolic meanings invested by a religious community. That the "capture" of space is neither symbolic nor real, but prescribed and regulated, tampers the "crowd power" that the processional literature presents.

\section{Conclusions}

Since 1964 when the Mohammedan procession erupted into riot, Singapore has been carefully managing the public expression of religion, and indeed, other processions involving assemblies of people and public displays of spectacle. This is understandable, particularly given how the preceding analysis endorses the view that processions are arenas for competing religious and secular discourses, and are multivocal, of social and political significance.

In focusing on the social and political dimensions of procession, I have illustrated how social relations (including family, friendship, and inter- and intra-community ties) are reinforced, challenged or watched over through participation in the event. I have also demonstrated how belief in egalitarian association on account of common participation in the event and mutual support among participants is misplaced. I conclude therefore that the traditional concept of communitas associated with pilgrimages and the notion of solidarity, belonging and group cohesion in processions perhaps remain relevant in some ways, but may have been over-extended in a somewhat romanticized notion of egalitarianism and bounded community. 
Politically, the processions are occasions when meanings are balanced and negotiated by state, temple and religious individual. These may revolve around the significance of sound in religious experience and the associated symbolic resistance to state prohibitions and temple regulations. They may be about the secular acknowledgement of religious time through suitable bracketing out of that time in the secular calendar. They may involve the ritual adjustments made to accommodate state modifications of sacred pathways. In all of this, the politics at work is not that of overt confrontation or party politics or grand strategy, but one of everyday negotiations and local level "tactics" (de Certeau 1984). Given Singapore's freedom of worship policy, time and space have been available for adherents to participate in the procession (despite some inconvenience). Participants have also been able to renegotiate meanings and values, finding ways to make music and pay homage to the "father" god. As a consequence, one of the conditions for the negative violence and aggression sometimes associated with religion in general and such events in particular is removed, that is, extreme feelings of deprivation in relation to practice of one's faith. However, the seeds of some dispirited and sometimes exasperated disappointment are present, directed at the constraints on religious music-making, the perverse and unintended encouragement it gives to rowdy noise-makers on the pretext of creating an aurally-defined sacred atmosphere for participants, the crowdedness of the event which lends itself to a channeling of frustrations towards "foreigners" and "youngsters", and the absence of an acknowledgement of this religious event via marking on the secular calendar, which is deemed to further contribute to early morning pre-workday crowdedness. Together, they have not seemed sufficient to constitute severe discontent. Nevertheless, it is imperative that these sources of irritation and discontent are recognized, with potential adjustments made to policy as circumstances change, for example, when the number of participants and observers grow, or when the profile of participants change.

Finally, that religious experience is a multifaceted one bears emphasis here. The geographer of religion is therefore required to go beyond a focus 
on the religious landscape of churches, temples, mosques, synagogues and so forth, as has hitherto been the primary focus. Certainly, sacred space is defined visually and materially through landscapes, but it is also constituted of soundscapes and timescapes, as the aural and temporal also contribute to the marking out of sacred space. Religion, to that extent, is an integrative institution, and religious experience may be best understood as a wholly integrated one, of sight, sound, emotion, time. It is only with this understanding that secular rules and regulations may be crafted to achieve pragmatic secular ends, particularly in multireligious urban contexts, while respecting religious imperatives.

\section{Bibliography}

\section{Bakhtin, Mikhail}

1968 Rabelais and His World. Trans. by Helene Iswolsky. Cambridge, MA: MIT Press.

\section{Campo, Juan Eduardo}

1998 American Pilgrimage Landscapes. - Annals of the American Academy of Political and Social Science 558, 40-56.

Davis, S. G.

1986 Parades and Power: Street Theatre in Nineteenth Century Philadelphia. Philadelphia: Temple University Press.

\section{De Certeau, Michel}

1984 The Practice of Everyday Life. Trans. Steven F. Rendail. Berkeley: University of California Press.

Eade, John \& Michael J. Sallnow (eds)

1991 Contesting the Sacred: The Anthropology of Christian Pilgrimage. New York: Routledge, Chapman and Hall.

\section{Eliade, Mircea}

1959 The Sacred And The Profane: The Nature Of Religion. Trans. from French by Willard R. Trask. San Diego: Harcourt Brace Jovanovich.

\section{Folch-Serra, M.}

1990 Place, Voice, Space: Mikhail Bakhtin's Dialogical Landscape. - Environment and Planning D: Society and Space 8, 255-274. 
Goheen, P. G.

1993 The Ritual of the Streets in Mid-19th-Century Toronto. - Environment and Planning D: Society and Space 11, 127-145.

\section{Graham, Brian \& Michael Murray}

1997 The Spiritual and the Profane: The Pilgrimage to Santiago de Compostela. - Ecumene, 4(4), 389-409.

Jackson, P.

1988 Street Life: The Politics of Carnival. - Environment and Planning D: Society and Space 6, 213-227.

Jurkovich, James M. \& Wilbert M. Gesler

1997 Medjugorje: Finding Peace at the Heart of Conflict. - The Geographical Review 87(4), 447-467.

Kaplan, T.

1984 Civic Rituals and Patterns of Resistance in Barcelona, 1890-1930. - P. Thane \& G. Crossick \& R. Floud (eds), The Power of the Past: Essays for Eric Hobsbawm, 173-194. Cambridge: Cambridge University Press.

Kong, Lily

1990 Geography and Religion: Trends and Prospects. - Progress in Human Geography 14(3), 355-371.

2001 Mapping "New" Geographies of Religion: Politics and Poetics of Modernity. - Progress in Human Geography 25(2), 211-233.

Kong, Lily \& B. S. A. Yeoh

1997 The Construction of National Identity Through the Production of Ritual and Spectacle: An Analysis of National Day Parades in Singapore. - Political Geography 16(3), 213-239.

\section{Lawrence, D.}

1982 Parades, Politics and Competing Urban Images: Doo Dah and Roses. - Urban Anthropology 4(2), 155-176.

Lee, T. S.

1999 Technology and the Production of Islamic Space: The Call to Prayer in Singapore. - Ethnomusicology 43, 86-100.

Lewis, C. \& S. Pile

1996 Woman, Body, Space: Rio Carnival and the Politics of Performance. - Gender, Place and Culture 3(1), 23-42.

\section{Marston, Sallie A.}

1989 Public Rituals and Community Power: St. Patrick's Day Parades in Lowell, Massachusetts, 1841-1874. - Political Geography Quarterly 8, 255-269. 


\section{Murray, Michael \& Brian Graham}

1997 Exploring the Dialectics of Route-based Tourism: The Camino de Santiago. - Tourism Management 18(8), 513-524.

National Archives website

http://www.knowledgenet.com.sg/ singapore/index.asp?title=NR/ NR.html\&hdr=NR

Straits Times, Singapore, various issues.

\section{Turner, Victor}

1974 Dramas, Fields and Metaphors. Ithaca: Cornell University Press.

Young, William C.

1993 The Ka'ba, Gender, and the Rites of Pilgrimage. - Middle East Studies $25,285-300$. 
